\title{
The Impact of Fuel Treatments on Wildfire Behavior in North American Boreal Fuels: A Simulation Study Using FIRETEC
}

\author{
Ginny Marshall 1,*, Dan K. Thompson ${ }^{1}{ }^{1}$, Kerry Anderson ${ }^{1, \dagger}$, Brian Simpson ${ }^{1} \mathbb{D}$, \\ Rodman Linn ${ }^{2}$ and Dave Schroeder ${ }^{3}$ \\ 1 Canadian Forest Service, Northern Forestry Centre, 5320 122st, Edmonton, AB T6H 3S5, Canada; \\ daniel.thompson@canada.ca (D.K.T.); kerryanderson@shaw.ca (K.A.); brian.simpson@canada.ca (B.S.) \\ 2 Los Alamos National Laboratory, Earth and Environmental Sciences Division, Los Alamos, NM 87545, USA; \\ rrl@lanl.gov \\ 3 Alberta Agriculture and Forestry, 9718107 St NW, Edmonton, AB T5K 2N6, Canada; \\ dave.schroeder@gov.ab.ca \\ * Correspondence: ginny.marshall@canada.ca \\ + This author has retired.
}

Received: 19 March 2020; Accepted: 27 May 2020; Published: 5 June 2020

check for updates

\begin{abstract}
Current methods of predicting fire spread in Canadian forests are suited to large wildfires that spread through natural forests. Recently, the use of mechanical and thinning treatments of forests in the wildland-urban interface of Canada has increased. To assist in community wildfire protection planning in forests not covered by existing operational fire spread models, we use FIRETEC to simulate fire spread in lowland black spruce fuel structures, the most common tree stand in Canada. The simulated treatments included the mechanical mulching of strips, and larger, irregularly shaped areas. In all cases, the removal of fuel by mulch strips broke up the fuels, but also caused wind speed increases, so little decrease in fire spread rate was modelled. For large irregular clearings, the fire spread slowly through the mulched wood chips, and large decreases in fire spread and intensity were simulated. Furthermore, some treatments in the black spruce forest were found to be effective in decreasing the distance and/or density of firebrands. The simulations conducted can be used alongside experimental fires and documented wildfires to examine the effectiveness of differing fuel treatment options to alter multiple components of fire behavior.
\end{abstract}

Keywords: fire modeling; FIRETEC; fire behavior

\section{Introduction}

Recently, the use of mechanical and thinning treatments for wildfire mitigation in the wildland-urban interface of Canada has increased; however, current methods of predicting fire behavior in Canadian forests are suited to large wildfires that spread through natural forests. North American fire behavior prediction systems, the National Fire Danger rating system (NFDRS) in the USA and the Canadian Forest Fire Danger Rating system (CFFDRS) in Canada [1,2], generally struggle at two scales: (1) large $\left(10^{2}-10^{4}\right)$ ha, plume or column driven wildfire events with time scales on the order of hours, where models based on small, wind-driven experimental fires or laboratory surface fires fail; (2) heterogeneous fuel structures (such as resulting from disturbances or thinning strategies), where models built upon homogenous fuels at the 1-5 ha scale suffer from an inability to represent changes in fuels structure at the scale of meters. For problem (1), coupled fire-atmosphere models linking meso-scale atmospheric models to the spread and energy release [3] are making strides at representing high-intensity wildfires, often building upon existing wildfire spread models. Problem (2) 
requires a completely different approach, where it would be unwise to use the existing semi-physical to empirical models at finer resolutions than they were designed for [4]. Moreover, in the realm of disturbances or forest thinning treatments that structurally alter the forest, it would be resource intensive to attempt to empirically characterize the response of wildfire spread and intensity on all manner of thinning treatments and forest modification across a range of fire conditions; rather, the strategy has been instead to build wildfire spread models from basic principles using a physics-based approach. One such implementation of a physics-based wildfire spread model that accounts for energy and mass movement at the meter scale is FIRETEC [5], which has been used successfully for over a decade to simulate wildfire behavior, primarily in dry conifer forest, shrublands, and grasslands. FIRETEC requires three-dimensional forest structure information, and it simulates the complex non-linear interactions between the atmosphere, the stand, and wildfire, such as combustion, radiative and convective heat transfer, turbulence, and drag [5]. The model has been used to successfully reproduce the spread of high-intensity crown fire in a boreal mixed pine and spruce forest from the International Crown Fire Modeling Experiment (ICFME) [6] and to examine mountain pine beetle impacts [7].

The simulation of the fuel structure of the ICFME experimental fires from Linn et al. [6] was a simplified realization of a well-drained and dense boreal forest stand that while common, does not represent the full range of boreal forest structure across North America. Spruce-dominated forests are a common boreal forest landcover, and specifically, black spruce (Picea mariana) comprises around 60\% of spruce-dominated stands across Canada, spruce being the most abundant tree genus in Canada [8]. Black spruce ranks as having the most vigorous fire behavior relative to other healthy (i.e., non-impacted by insects) forest fuel types in the Canadian Fire Behavior Prediction system [9]. Retrospective studies also show that black spruce stands burn with higher intensity [10] compared to other forest cover types, and is a key driver in the greater rates of fire intensity and spread in North America compared to Eurasia [11]. In the wake of the 2011 Slave Lake wildfires in Alberta, Canada, the Province of Alberta prioritized the treatment of black spruce stands near communities in their FireSmart community wildfire mitigation practices [12]. Given the dominance of black spruce cover across boreal Canada and Alaska, it is likely that the plurality of boreal community forest thinning treatments take place in this fuel complex. Thinning treatments in black spruce are often performed using whole-tree mastication (mulching), where branch and stemwood are broken into fragments between $0.5-5 \mathrm{~cm}$ in diameters and 10-30 cm long [13] and left remaining on the forest floor.

Despite the abundance of spruce fuels and the increasing frequency of fuel treatments in forests adjacent to boreal forest communities, little definitive research is available on the topic. In Alaska, limited observations and modeling support the concept that thinning in black spruce reduces fire intensity [14-16], and case studies in Saskatchewan support the idea that thinned forest makes air tanker use more effective [17]. However, an experimental fire in boreal spruce using a widespread strip mulch treatment showed only a modest reduction in the intensity of crown fire, but with little to no reduction in the rate of spread [13]. With a limited number of case studies available, a physics-based wildfire modelling approach is an economical and practical approach to understand the combination of weather conditions and treatment designs that might lead to effective wildfire mitigation near communities. In the absence of such physics-based models that allow the exploration of the permutations of fuels, fuels treatments, and weather conditions in the boreal, guidance based solely on experimental crown fires would require an effort many times larger than ICFME [18]. However, by using this numerical approach to develop phenomenological understanding and a hypothesis that can be experimentally tested, it might be possible to focus and reduce the size of such future efforts.

The use of fire physics models, such as FIRETEC, is not without controversy, with some authors correctly stating that fire physics models cannot capture basic processes not explicitly identified and captured in the design and formulation of the model and associated computer code [19]. However, in this particular study, we seek to examine how fire behavior is altered by changing single components of a simulated fire environment, such as the orientation of mulch strips, rather than replicate findings 
from empirical fire growth models in natural stands. We focus on changes on the margin (or compared to a control stand of the exact same trees) rather than the absolute value.

To aid in mitigation and planning for community protection and to better understand the efficacy of fuel treatments, we use FIRETEC to simulate fire spread in lowland black spruce. We apply four different mulching fuel treatments to a control stand and examine how fire behavior changes in each of these treatments for each of four different weather scenarios. Since mechanical fuel treatments are utilized frequently as a method of mitigation around communities, here we simulate and compare fire behavior in parallel strip mulching along and across the mean wind direction, and irregular cluster retention mulching, retaining both naturally dense patches and naturally thin patches. Furthermore, we examine the effects of these treatments on the production and travel distance of firebrands.

\section{Materials and Methods}

FIRETEC requires detailed information about the three-dimensional structure of the fuels complex, including moisture content, surface area to volume ratio (via size scale), and fuel density within each grid cell. Specifications for the location, timing, and temperature ramp rates for ignition must also be provided. Furthermore, the model requires information about wind and by default generates a logarithmic wind profile from user defined mean wind speed and direction at a known height. Optionally, the model produces firebrands based on firebrand size and shape specifications, as well as user defined launch criteria.

The remainder of this section will describe the study simulation domain, ignition prescription, the five fuel configurations, the four weather scenarios applied to each fuel configuration, and the fire brand specifications. In total, 20 simulations were completed for the black spruce fuel complex.

\subsection{Simulation Set-Up}

The simulations are conducted in a three-dimensional domain, where the horizontal area is $480 \mathrm{~m} \times 480 \mathrm{~m}$ (at $2 \mathrm{~m}$ resolution), and the depth is $600 \mathrm{~m}$, with 41 grid cells in the vertical direction. The vertical grid cells are stretched such that the resolution at the surface is approximately $1.6 \mathrm{~m}$, and the domain is oriented so that the ambient wind moves in the positive $x$-direction. The upwind region contains sparse or "burned" fuels stretching the crosswind width of the domain (from 0 to $480 \mathrm{~m}$ on the $\mathrm{y}$-axis), and from the inlet to $80 \mathrm{~m}$ in the streamwise direction (from 0 to $80 \mathrm{~m}$ on the $\mathrm{x}$-axis). A region of control fuels (untreated) reaches from this upwind burned structure for the next $120 \mathrm{~m}$ in the streamwise direction (from 80 to $200 \mathrm{~m}$ in $\mathrm{x}$-direction), spanning the entire domain in the crosswind or y-direction, followed by the relevant treatment from 200 to $480 \mathrm{~m}$. Domain orientation and fuel treatment structure can be seen in Figure 1.

\subsection{Weather and Fine Fuel Moisture Content}

Weather scenarios applied to each fuel configuration are plausible, covering a realistic range of fire weather (and by extension, fuel moisture) conditions observed within Alberta, Canada during the active fire season. We prescribed a low and high fuel moisture (9\% and $14 \%$ water content of fine fuels) and a low and high wind speed $\left(12 \mathrm{~km} \mathrm{~h}^{-1}\right.$ and $\left.25 \mathrm{~km} \mathrm{~h}^{-1}\right)$, while holding all other variables constant. For brevity, the scenarios will be labelled MC 9 or MC 14 and WS 12 or WS 25. The corresponding rate of spread (ROS; $\mathrm{m} \mathrm{min}^{-1}$ ) predicted by the Canadian Forest Fire Behavior Prediction (FBP) System [9] (a subsystem of the CFFDRS), for these combinations of wind speed and fine fuel moisture (shown in parenthesis as WS/MC), are 5 (12/16), 14 (12/9), 14 (25/16), 32 (25/9), and are derived from a climatology of fire weather near Slave Lake, Alberta. The lower end and higher end of ROS correspond to the 70th percentile and 98th percentile of the Initial Spread Index of the Canadian Forest Fire Weather Index (FWI) System [20] (a subsystem of the CFFDRS), which is an abstract rating for predicted ROS. The predicted ROS of $14 \mathrm{~m} \mathrm{~min}^{-1}$ corresponds to both WS 12 MC 9 and WS 25 MC 16, to ensure that the model is capturing similar fire behavior that is driven by wind and moisture content in the fine fuels separately. 

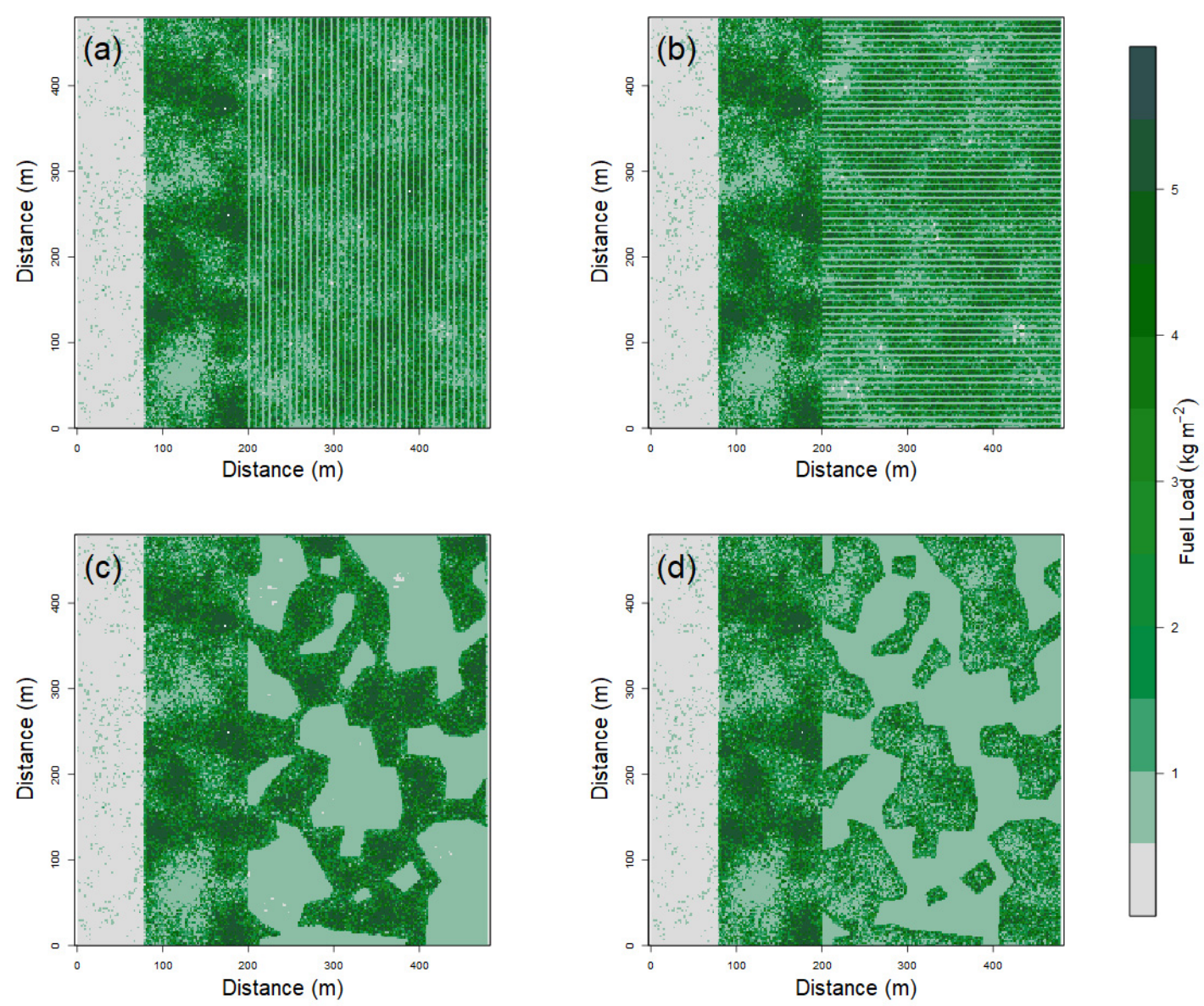

Figure 1. Mulch fuel treatment configuration for (a) perpendicular strips, (b) parallel strips, (c) cluster treatment: thin removed, and (d) cluster treatment: dense removed. Control scenario not shown. Each treatment scenario removes $50 \%$ of the treed areas.

An initial wind simulation absent of fire is completed for each wind speed scenario to ensure steady state wind and turbulent profiles are achieved over the upwind fuel configuration (i.e., sparse or "burned" upwind fuels). For these wind-only simulations, the wind field is initialized with cyclic boundary conditions over a sparse stand, and thus the wind can cycle through the domain until it is fully developed. Once the turbulent flow is fully developed, the dynamic boundary conditions from the wind-only simulations are stored, providing a time series of conditions for the boundaries of the fire simulations, as well as an initial condition for startup. This ensures that wind entering the control and treated domain before and during the wildfire simulation is representative of wind moving through sparse fuels approaching the ignition line. The wind is specified to be $4.5 \mathrm{~m} \mathrm{~s}^{-1}$ and $9.0 \mathrm{~m} \mathrm{~s}^{-1}$ at a height of $38.0 \mathrm{~m}$, corresponding to roughly $12 \mathrm{~km} \mathrm{~h}^{-1}$ and $25 \mathrm{~km} \mathrm{~h}^{-1} 10 \mathrm{~m}$ open wind speed, respectively.

\subsection{Stand Structure}

The fuel structure used in the lowland black spruce simulations follows the intensive pre-fire fuel sampling conducted by the Alberta Wildfire Fuel Inventory Program (AWFIP) for the Red Earth Creek prescribed burn in 2015 [13]. See Supplementary Material Document S1 for a complete description of the conversion of fuel inventory data to FIRETEC fuel density inputs. A total of 9400 black spruce stems per ha were simulated as per the plot measurements, resulting in a canopy fuel load of $2.5 \mathrm{~kg} \mathrm{~m}^{-2}$, fully three times larger than the standard C-2 boreal spruce fuel type in the Canadian FBP system. The median crown base height of all large trees was measured and modelled as $1.8 \mathrm{~m}$, although a height-weighted average of live crown base height results in a higher estimate of $2.4 \mathrm{~m}$ in the model 
domain. Using the $2.4 \mathrm{~m}$ crown base height, the crown bulk density in the canopy is $0.26 \mathrm{~kg} \mathrm{~m}^{-3}$, significantly higher than the $0.16 \mathrm{~kg} \mathrm{~m}^{-3}$ for the Canadian FBP C-2 fuel type (assuming a $5 \mathrm{~m}$ canopy height and zero canopy base height). Both of these values are markedly lower than the nominal $3 \mathrm{~m}$ canopy base height used in the FBP C-2 fuel, though the text description of the C-2 fuel type indicates that "tree crowns extend nearly to ground". Foliar moisture content of the spruce needles was prescribed to be $86 \%$, similar to values from the Red Earth Creek research burn, and corresponding to spring values measured in other black spruce sites in North-Central Alberta [21]. Litter and fine woody debris, as well as small trees (those less than $1.6 \mathrm{~m}$ tall, corresponding to the lowest cell in the FIRETEC domain) added 0.4 and $0.45 \mathrm{~kg} \mathrm{~m}^{-2}$, respectively. Within the upwind burned zone, the number of stems is approximately $5 \%$ of the control fuel, and each of the remaining trees contains $50 \%$ of the branchwood relative to the control, with no foliage or lichen.

\subsection{Fuel Treatments}

Four different mulching fuel treatments were applied to the original untreated domain, resulting in $50 \%$ of the treatment area being mulched in each scenario (see Figure 1). These treatments simulate a purely mechanical mulch treatment, with no additional hand thinning or pruning of canopy fuels, and all mulch was assumed to remain on the ground. Perpendicular and parallel mulch strips (relative to the fire spread and wind direction) are $4 \mathrm{~m}$ wide at the base, corresponding to multiples of the $2 \mathrm{~m}$ diameter grid cells of the FIRETEC domain. Stems were removed in cells specified as mulch treatments; however, branches from unaltered trees adjacent to the mulch strips may be averaged in the grid cells identified as mulched cells. The mulched biomass from each tree (within treated areas) is distributed evenly in the 9 cells surrounding the stem, so that some mulch may be distributed into untreated cells. Mulch available to burn is a function of fine fuel moisture content, where the burn rate is $0.25 \mathrm{~kg} \mathrm{~m}^{-2} \mathrm{~min}^{-1}$ for $14 \%$ moisture content, and $0.345 \mathrm{~kg} \mathrm{~m}^{-2} \mathrm{~min}^{-1}$ for $9 \%$ [22]. The bulk density of mulch is $120 \mathrm{~kg} \mathrm{~m}^{-3}$, and we assume a flame front residence time of 1.5 minutes. Using these assumptions, we prescribe the depth of the mulch limited by the burn rate, resulting in slightly more fuel available in the drier scenario. Within the treated cells, we assume the only available surface fuels are mulch, litter and fine woody debris, and within the untreated cells, litter, fine woody debris, shrubs, seedlings or moss, and mulch (in treatment-adjacent cells) are also available (see Supplementary Table S1).

Cluster retention treatment is not a widespread fuel treatment currently in Alberta, but given the large spatial variance in stems density and canopy fuel load observed in lowland black spruce [23], it was hypothesized that irregular treatments in non-regular geometry, similar to retention harvesting techniques, may offer more efficient reductions in fire behavior, owing to larger and more contiguous mulch areas where fire spread rates are reduced. Furthermore, cluster retention treatments are generally more desirable near communities, since they are more esthetically pleasing than strip mulch. Two cluster retention treatments, each $50 \%$ by area, were simulated: thin removed where the area of the lower stem density was mulched, leaving only dense standing black spruce features, and dense removed, where the exact opposite areas of the domain where mulched, leaving only sparsely treed areas intact. In the thin removed treatment, the mean canopy fuel load in the remnant areas increased to $3.2 \mathrm{~kg} \mathrm{~m}^{-2}$, with a canopy bulk density of $0.33 \mathrm{~kg} \mathrm{~m}^{-3}$. In the dense removed treatment, the sparse remnant black spruce fuel loading was reduced to $1.5 \mathrm{~kg} \mathrm{~m}^{-2}$ or approximately $0.16 \mathrm{~kg} \mathrm{~m}^{-3}$. In reality, natural openings in black spruce stands often result in lower mean tree height, but this interaction was not explicitly modelled here, meaning that mean tree height does not vary between the control and any of the cluster treatments.

\subsection{Ignition}

Ignition occurs along the edge of the upwind control fuels ( $80 \mathrm{~m}$ from the inlet) and the temperature in the bottom cell is ramped up from ambient (approximately $300 \mathrm{~K}$ or $\left.26{ }^{\circ} \mathrm{C}\right)$ to $800 \mathrm{~K}\left(530{ }^{\circ} \mathrm{C}\right.$ ), at a ramp rate of $100^{\circ} \mathrm{C} \mathrm{s}^{-1}$, beginning $10 \mathrm{~s}$ after the simulation is initialized. The ignition line is $280 \mathrm{~m}$ 
long and is domain-centered in the y-direction, extending 2 grid cells deep in the positive $\mathrm{x}$-direction; i.e., ignition occurs where $80 \leq \mathrm{x} \leq 84 \mathrm{~m}$, and $100 \leq \mathrm{y} \leq 380 \mathrm{~m}$.

\subsection{Firebrands}

Since little is known definitively about firebrand geometry and abundance, fixed firebrand physical properties and potential density is used. We assume the firebrands are a cylinder with length to radius ratio of 3:1, approximately the ratio of a black spruce cone. The density of each firebrand is $120 \mathrm{~kg} \mathrm{~m}^{-3}$, and the size of the brand is determined by how big the local winds can lift, based on terminal velocity approximation. However, the minimum radius of each firebrand must be $7 \mathrm{~mm}$ or greater, to ensure that only cone-sized brands are launched. The drag coefficient for the cylinder is assumed to be 1.0 and the cylinder burns in the radial direction (the length remains unchanged). Launching occurs 5 times per second, but firebrands are simulated only if conditions for temperature $(600 \mathrm{~K})$, size (greater than $7 \mathrm{~mm}$ radius), and sufficient updraft are met. Brands can be launched over the entire tree height. For further information on the firebrand model, see [24].

\section{Results}

In all treatments, the reduction in overall fuel load and associated wind drag allowed a significant increase in wind speeds near the ground (see Table 1), relative to the untreated control stand. At $2.2 \mathrm{~m}$ above ground level, the domain-averaged mean wind speed increased by up to three times that observed in the control.

Table 1. Surface wind speeds (WS, $\mathrm{km} \mathrm{h}^{-1}$ ) in differing black spruce treatments under a $25 \mathrm{~km} \mathrm{~h}^{-1}$ open wind speed measured at $10 \mathrm{~m}$ height. Relative wind speed values are a ratio of treatment to control.

\begin{tabular}{lcccc}
\hline Treatment & WS at $\mathbf{0 . 7} \mathbf{~}$ & $\begin{array}{c}\text { WS Relative } \\
\text { to Control at } \mathbf{0 . 7} \mathbf{~}\end{array}$ & WS at $\mathbf{2 . 2} \mathbf{~ m}$ & $\begin{array}{c}\text { WS Relative } \\
\text { to Control at } \mathbf{2 . 2} \mathbf{~ m}\end{array}$ \\
\hline Control & 1.51 & 1 & 1.83 & 1 \\
\hline Parallel strips & 2.50 & 1.66 & 3.78 & 2.07 \\
Perpendicular & 1.92 & 1.28 & 2.69 & 1.47 \\
Dense removed & 3.49 & 2.32 & 5.40 & 2.95 \\
Thin removed & 3.43 & 2.28 & 4.78 & 2.62 \\
\hline
\end{tabular}

In the control plots, domain-averaged rate of spread (time required for the simulation to cross the $280 \mathrm{~m}$ treatment area) was $23-24 \mathrm{~m} \mathrm{~min}^{-1}$ in the two WS 12 scenarios (with $14 \%$ and $9 \%$ fine fuel moisture), as shown in Table 2. At WS 25, the domain-averaged rate of spread was $38 \mathrm{~m} \mathrm{~min}^{-1}$ in both fuel moisture scenarios. As an alternate method of calculating rate of spread that encompasses both head and flank fires from the line ignition, median per-pixel rate of spread was calculated as 17 and $21 \mathrm{~m} \mathrm{~min}^{-1}$ in the WS 12 and 25 scenarios, respectively. The crown fraction burned in the $12 \mathrm{~km} \mathrm{~h}^{-1}$ wind scenarios was $80 \%$ and increased to $85 \%$ in the faster wind scenarios, which in both cases can be considered, approximating a continuous crown fire (the FBP formally uses a cut-off of $90 \%$ ).

With an understanding of the controls on rate of spread in the boreal lowland spruce fuel complex, the relative impact of simulated fuel treatments on rate of spread and intensity can be interpreted. The strip mulch parallel to the wind had the smallest impact on the domain-average rate of spread, decreasing the ROS by $8-10 \%$ in the two WS 12 scenarios. At WS 25, the rate of spread increased by $20 \%$ relative to a control stand with no treatment, and with no dependence on fine fuel moisture content whatsoever (Figure 2). 
Table 2. Head fire rate of spread (ROS), median per-pixel ROS, head fire intensity (HFI), crown fuel consumption (CFC), surface fuel consumption (SFC), surface fuel load, canopy fuel load and number of stems for each scenario. The mean stand height and live crown base height are $12 \mathrm{~m}$ and $2.4 \mathrm{~m}$ respectively for all scenarios. * Median per pixel rate of spread with flank fire. ** Average canopy fuel load for cells with canopy fuel.

\begin{tabular}{|c|c|c|c|c|c|c|c|c|c|c|c|}
\hline $\begin{array}{c}\mathrm{WS} \\
\left(\mathrm{km} \mathrm{h}^{-1}\right)\end{array}$ & MC (\%) & ISI & Treatment & Stems (per ha) & $\begin{array}{l}\text { Surface Fuel Load } \\
\quad\left(\mathrm{kg} \mathrm{m}^{-2}\right)\end{array}$ & $\begin{array}{l}\text { Canopy Fuel Load } * * \\
\left(\mathrm{~kg} \mathrm{~m}^{-2}\right)\end{array}$ & $\begin{array}{c}\text { Mean SFC } \\
\left(\mathrm{kg} \mathrm{m}^{-2}\right)\end{array}$ & $\begin{array}{c}\text { Mean CFC } \\
\left(\mathrm{kg} \mathrm{m}^{-2}\right)\end{array}$ & $\begin{array}{l}\text { Head Fire ROS } \\
\quad(\mathrm{m} \mathrm{min}-1)\end{array}$ & $\begin{array}{l}\text { Per-Pixel ROS } \\
\left(\mathrm{m} \mathrm{min}^{-1}\right)\end{array}$ & $\begin{array}{c}\text { Median HFI } \\
\left(\mathrm{kW} \mathrm{m}^{-1}\right)\end{array}$ \\
\hline 12 & 14 & 5 & Control & 9406 & 1.12 & 2.53 & 0.6 & 2.0 & 23.5 & 17.4 & 12,100 \\
\hline 12 & 14 & 5 & Parallel strips & 5579 & 1.11 & 1.80 & 0.9 & 1.6 & 21.1 & 15.1 & 7300 \\
\hline 12 & 14 & 5 & Perpend. strips & 5577 & 1.12 & 1.79 & 0.9 & 1.5 & 13.4 & 11.8 & 6000 \\
\hline 12 & 14 & 5 & Dense Removed & 3665 & 0.93 & 1.50 & 0.7 & 1.1 & 0.9 & $1.5 / 0.6 *$ & 415 \\
\hline 12 & 14 & 5 & Thin Removed & 7469 & 1.00 & 3.24 & 0.7 & 1.9 & 0.2 & $0.02 / 1.2$ * & 10 \\
\hline 12 & 9 & 10 & Control & 9406 & 1.12 & 2.53 & 0.6 & 2.0 & 24.4 & 17.9 & 12,000 \\
\hline 12 & 9 & 10 & Parallel strips & 5579 & 1.24 & 1.80 & 1.0 & 1.6 & 22.5 & 15.7 & 8200 \\
\hline 12 & 9 & 10 & Perpend. strips & 5577 & 1.24 & 1.79 & 1.0 & 1.6 & 17.3 & 13.8 & 7400 \\
\hline 12 & 9 & 10 & Dense Removed & 3665 & 1.01 & 1.50 & 0.8 & 0.9 & 2.0 & $2.2 / 1.8^{*}$ & 575 \\
\hline 12 & 9 & 10 & Thin Removed & 7469 & 1.08 & 3.24 & 0.8 & 1.9 & 1.4 & $2.2 / 0.9 *$ & 891 \\
\hline 25 & 14 & 10 & Control & 9406 & 1.12 & 2.53 & 0.6 & 2.1 & 38.4 & 20.6 & 15,100 \\
\hline 25 & 14 & 10 & Parallel strips & 5579 & 1.11 & 1.80 & 0.9 & 1.6 & 45.8 & 25.2 & 11,900 \\
\hline 25 & 14 & 10 & Perpend. strips & 5577 & 1.12 & 1.79 & 0.8 & 1.6 & 37.0 & 22.0 & 10,100 \\
\hline 25 & 14 & 10 & Dense Removed & 3665 & 0.93 & 1.50 & 0.7 & 1.3 & 1.6 & $2.7 / 1.0 *$ & 802 \\
\hline 25 & 14 & 10 & Thin Removed & 7469 & 1.00 & 3.24 & 0.7 & 2.1 & 1.6 & $2.7 / 0.9 *$ & 1122 \\
\hline 25 & 9 & 20 & Control & 9406 & 1.12 & 2.53 & 0.6 & 2.2 & 38.4 & 20.6 & 15,500 \\
\hline 25 & 9 & 20 & Parallel strips & 5579 & 1.24 & 1.80 & 1.0 & 1.6 & 46.3 & 25.3 & 13,200 \\
\hline 25 & 9 & 20 & Perpend. strips & 5577 & 1.24 & 1.79 & 0.9 & 1.6 & 37.1 & 23.2 & 11,200 \\
\hline 25 & 9 & 20 & Dense Removed & 3665 & 1.01 & 1.50 & 0.8 & 1.1 & 2.7 & $4.7 / 1.5^{*}$ & 1331 \\
\hline 25 & 9 & 20 & Thin Removed & 7469 & 1.08 & 3.24 & 0.8 & 2.5 & 4.1 & $8.9 / 1.9 *$ & 4420 \\
\hline
\end{tabular}




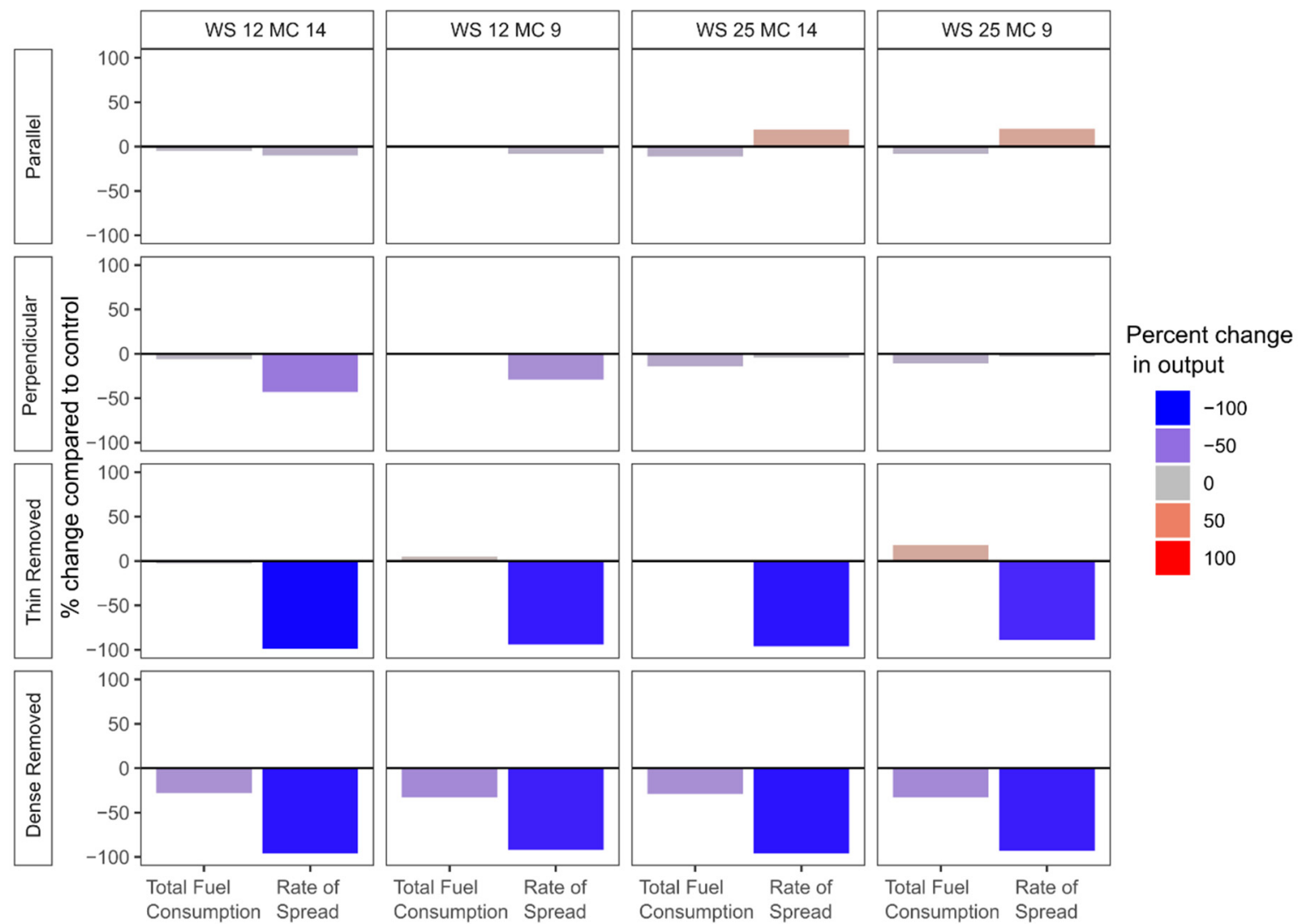

Figure 2. Fuel consumption and rate of spread change for each treatment and weather scenario in the black spruce fuel type. All changes are percent change relative to the control simulation in the same weather scenario.

Mulch strips perpendicular to the wind provided superior reductions in fire behavior compared to parallel strips. Moisture content values did have an impact of domain-averaged ROS, with a $43 \%$ reduction in ROS simulated in the parallel strip mulch for WS 12 and MC 14; with an 9\% moisture content, the reduction in ROS was only $29 \%$. For WS 25 scenarios, a reduction in ROS of $3-4 \%$ was observed in both moisture scenarios. Total fuel consumption varied little between the control and all weather scenarios, with a $0-14 \%$ reduction, largely owing to an increase in surface fuels (i.e., mulch), and a $30 \%$ reduction in canopy fuel load, due to the mulching process. Accordingly, the reduction in head fire intensity was most efficient in the parallel strip mulch under lower winds (36\% and $22 \%$ reductions in the fine fuel moisture content for $14 \%$ and $9 \%$ scenarios).

The thinning of the natural openings in spruce (leaving only the naturally dense fractions of the stands) had a dramatic impact on landscape-level rate of spread in all simulations, largely owing to the slow rate of spread in large ( $>100 \mathrm{~m}$ in diameter) mulched areas. Unlike the control of strip mulch simulations where humidity had little to no effect on ROS, we discretely simulated the moisture content of the surface of the mulch bed and amount of available fuel in mulch as a function of FFMC. As a result, forward rate of spread in the mulch increased from $0.9-1.2 \mathrm{~m} \mathrm{~min}^{-1}$ at combinations of low wind speed or fine fuel moisture content to $1.9 \mathrm{~m} \mathrm{~min}^{-1}$ at WS 25 and MC 9. Given the fairly low fuel loading of mulch $\left(0.02-0.03 \mathrm{~kg} \mathrm{~m}^{-2}\right)$ that is available for flaming combustion, the resultant head fire intensity values of $100-300 \mathrm{~kW} \mathrm{~m}^{-1}$ in the mulch only (not shown) were a poor carrier of fire to the remnant spruce stands, which themselves had to accelerate from a surface fire. This stop-start nature of the fire spread, with each remnant tree stand having to ignite from a low-intensity surface fire lowered the remnant rate of spread to $2.2-2.7 \mathrm{~m} \mathrm{~min}^{-1}$ in both the intermediate scenarios. Only in the WS 25 MC 9 scenario did the higher intensity in the mulch have a strong influence on the ignition in the remnant stands, resulting in a three-fold increase in the rate of spread to $8.9 \mathrm{~m} \mathrm{~min}^{-1}$. 
The mulching of the dense portions of the simulation domain with residual patches composed of naturally sparse treed areas was a more dramatic fuel reduction in terms of stem removal, but resulted in largely similar fire behavior outcomes. The only substantial difference in rate of spread is in the WS $25 \mathrm{MC} 9$ scenario, where the rate of spread decreased from 8.9 to $4.7 \mathrm{~m} \mathrm{~min}^{-1}$ from the thin removed to the dense removed treatment. The halving of the rate of spread with a halving of canopy fuel load (and canopy bulk density) is a stronger reduction in fire behavior compared to the statistical model of Cruz and Alexander [25] that incorporates a canopy bulk density term, which suggests only a $16 \%$ reduction in rate of spread in continuous conifers after a halving of the fuel load. Additional domain-averaged fire behavior information not discussed here can be found in Supplementary Table S2.

In the black spruce fuel complex, firebrand travel distances and production densities were lower at WS 12, averaging 38-41 firebrands $\mathrm{m}^{-2}$ and $99 \%$ distances of $127 \mathrm{~m}$, with little dependence of moisture content. At higher wind speeds, more firebrands were produced $\left(57-70 \mathrm{~m}^{-2}\right)$, and distances increased dramatically to over $200 \mathrm{~m}$, an increase of 70\% (Figure 3). Fuel treatments were effective at WS 12 in decreasing both firebrand density and travel distance, with the thin removed treatment primarily impacting firebrand travel distance (a 38\% decrease) with little impact on density; while perpendicular strips primarily impacted density ( $75 \%$ decline) with no impact on distances. Parallel strip mulching treatments showed a strong impact in decreasing firebrand density ( $68 \%$ decline), with a modest decrease in travel distance. For both strip treatments at this lower wind speed, it is notable that the decrease in firebrand density (68-75\%) exceeds the $50 \%$ fuel reduction, suggesting this treatment achieves a leveraged impact on firebrand density. The dense removed treatment was the most effective overall, causing a density decline on par with the thin removed treatment and a distance decline equal to the perpendicular strip mulching treatment.

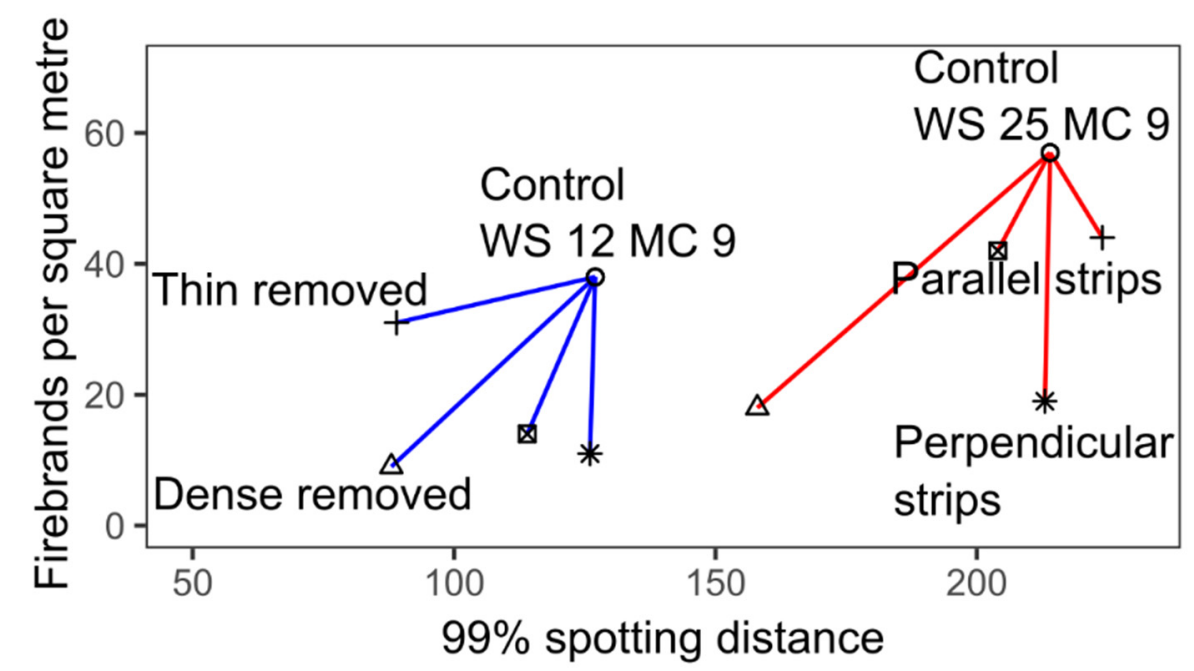

Figure 3. Firebrand travel characteristics for FIRETEC simulations of medium-range firebrand travel. The control (untreated) simulation is represented by a circle, and changes in firebrand travel are represented by another symbol connected to the control values by a colored line. The firebrand travel distance on the $x$-axis represents the maximum distance of $99 \%$ of the firebrands, i.e., excluding the travel distance of the furthest $1 \%$.

At the higher $25 \mathrm{~km} \mathrm{~h}^{-1}$ wind speed, the impact of fuel treatments was similar in the dense removed and perpendicular strip mulching, both with a 50\% reduction in firebrand density, and a $27 \%$ reduction in firebrand travel distance in the dense removed treatment. The parallel strip treatment was less effective at higher wind speeds, creating only a $32 \%$ reduction in firebrand density and a small $5 \%$ reduction in travel distance, despite a 50\% reduction in fuel load. Notably, the thin removed treatment caused a similar 30\% reduction in firebrand density (with all treatments impacting $50 \%$ of the total area), but a slight $5 \%$ increase in travel distance was observed. 


\section{Discussion}

The fire behavior objectives for fuel treatments used by practitioners are frequently qualitative and seek to limit the potential for crown fire, minimize the generation of flying embers, or enhance fire suppression effectiveness. Since all possible outcomes across scenarios of fuel geometry, fire ignition, and weather are difficult to fully compute, it is preferable to generalize many of the lessons from simulation studies to the real world. In this study, we emphasize the relative impacts of fuel treatments relative to a single control forest domain, each of which represents only a single iteration amongst all the possible variations on lowland spruce forests of the boreal zone. While the absolute rate of spread may vary due to individual stand characteristics and fire weather, the relative impacts of fuel treatment on fire behavior can be more confidently interpreted as a relative rate of change, as shown by the relative rate of spread and fuel consumption in Figure 2, relative impacts on surface wind speed, or impacts on firebrand travel distance and density. These simulations provide a baseline from which fire managers can build expectation for fuel treatment impacts on fire behavior.

Relative to the baseline scenarios, the mulch strips parallel with the wind had little to no reduction in ROS for the lower wind speed scenarios, and in fact, the modeled ROS is greater than the baseline in higher wind speed scenarios. This is largely due to the reduced drag encountered in the long, straight, open corridors leading to increases in near surface wind and subsequently increased rate of spread rate through the surface and canopy fuels. While we observe a reduction in the ROS, for the lower wind speed scenarios when the wind is oriented perpendicular to mulched strips, little reduction in ROS is observed for the higher wind speed scenarios. Comparison between the mulching strip scenarios suggests that strip mulch oriented perpendicular to the wind direction more effectively reduces the rate of spread, head fire intensity and fuel consumption than a strip mulch parallel to the wind in low wind speed scenarios, however, neither orientation reduces rate of spread in higher winds, where only modest reductions in head fire intensity are observed. This is consistent with findings at the Red Earth Creek experimental fire [13], where $4 \mathrm{~m}$ wide strip mulch perpendicular to wind direction had little effect on fire behavior, despite the reduction in large black spruce stems from $1450 \mathrm{stems} \mathrm{ha}^{-1}$ to 650 stems ha ${ }^{-1}$ in wind speeds near $20 \mathrm{~km} \mathrm{~h}^{-1}$ and fine fuel moisture content around $7 \%$. They suggest that widening strips could modestly decrease intensity, but is unlikely to reduce spread rates.

Furthermore, while both strip mulch treatments resulted in a reduction in the number of firebrands produced per square meter (largely due to a reduction in fuel load), the reduction in number of firebrands at higher wind speed was less than $50 \%$ for all treatments, whereas the fuels reduction was $50 \%$ by area. In both treatments and both wind scenarios, there was little to no reduction in the $99 \%$ percentile of spotting distance. Together, the results from the Red Earth Creek experimental burn and the simulations here suggest that strip mulching does not provide significant decrease in number of firebrands produced relative to the fuels reduction, nor does it decrease fire behavior in drier and windier scenarios, regardless of the orientation or width.

Cluster retention treatment had the greatest impact on the rate of spread and head fire intensity for all weather scenarios, where the head fire ROS was reduced by $90 \%$ or greater, relative to the control. For all scenarios and both treatments, the large fuel breaks between clusters of trees prevented or dramatically slowed continuous crown fire. During each simulation, when the head fire reached an open mulched patch, it was forced to the surface, which has low fuel availability, significantly reducing forward rate of spread and intensity. Interestingly, while the number of firebrands produced was decreased in both treatments, at the higher wind speed scenario, the thin removed treatment resulted in an increase in firebrand distance. In the thin removed treatment, although the number of stems throughout the entire study area decreased and $50 \%$ by area was treated, the average canopy fuel load increased. More fuel available in the dense patches and increased wind and oxygen availability in adjacent open patches could result in stronger updrafts able to loft firebrands higher and further downwind (not shown).

Other studies of fuel treatment impacts on fire behavior follow a similar structure to this study, whereby individual factors are isolated in order to examine their marginal impacts. Burke [26], using 
the WFDS fluid dynamics model, examined fire behavior in western US Ponderosa pine, a mature pine fuel structure with higher crown base height $(4 \mathrm{~m})$, not examined in this study. A $64 \%$ stem removal simulation (with no raising of crown base height) decreased crown fraction burn from $40 \%$ to less than $10 \%$, only when accompanied by lower surface fuel loads $\left(0.5 \mathrm{~kg} \mathrm{~m}^{-2}\right)$. Higher surface fuel loads $\left(1.86 \mathrm{~kg} \mathrm{~m}^{-2}\right.$ ) maintained continuous crown fires ( $>90 \%$ crown fraction burned), regardless of thinning practices. Surface fuel load was not directly manipulated in any simulations in this study. Parsons et al. [27] simulated the transition from a crown fire to a surface fire, with heavy thinning ( $50 \%$ of basal area) in mature lodgepole pine following trends, consistent with the statistical/empirical analysis from Cruz et al. [25]

Zeigler et al. [28] recreated pre-treatment stand structure for stands in the Western USA, using maps of stems and stumps leftover after thinning operations. They found that approximately $50 \%$ reductions in basal area in mature mixed conifer stands resulted in a consistent decline in crown fraction burned from between 40 and $50 \%$ to less than $30 \%$ in all cases; reductions in rate of spread and intensity were relatively larger with increasing wind speeds much higher than those used in this study (as high as $46 \mathrm{~km} \mathrm{~h}^{-1}$ ). Unlike most fully-simulated environments where stem clustering and thinning follows natural approximations, stem mapping post-treatment revealed a strong preference for stem reduction in the natural clusters of conifers, approximating some of the patterns seen in the dense removed treatment of the black spruce stand simulated in this study. Black spruce peatland stands also tend to be clumpy with frequent small openings due to disturbance and microtopography, and conceptually, this pattern emulates the structure described by Zeigler et al. As such, the dense removed treatment may emulate natural black spruce structural patterns better than the other treatment types.

Surface wind speed, as examined in this study, is infrequently reported in fire physics simulations of fuel treatment, despite being computed by necessity in models such as FIRETEC or WFDS. Hoffman et al. [7] simulated wind speeds in 5-year-old ( $60 \%$ grey dead trees without needles, $40 \%$ live) mountain pine beetle outbreak. With the loss of $60 \%$ of the needles in the canopy, surface wind speeds were simulated to increase 4 -fold, with slightly larger increases in patchy outbreaks, with larger continuous patches of dead standing trees without needles. These wind speed ratios may be used to inform surface ignition models based on in-stand wind speeds, or as a tool to assess increasing fuel drying rates after fuel treatment, as wind is a major driver of surface fuel drying [29]. In this study, surface wind speed and direction also show the presence of advantageous contraflow rotors at the windward side of cluster mulch treatments, that may slow down surface fire spread immediately upwind of tree clusters (not shown).

The FBP system prediction for the black spruce fuel type places a strong emphasis on air relative humidity (and therefore moisture content in the fine fuels), impacting forward rate of spread, with FBP predictions for the $12 \mathrm{~km} \mathrm{~h}^{-1}$ wind speed of 5 and $14.5 \mathrm{~m} \mathrm{~min}^{-1}$ for moisture content, $14 \%$ and $9 \%$, respectively. For WS 25 scenarios, the FBP predictions infer a strong moisture content dependence, with domain rate of spreads of 13.4 and $32 \mathrm{~m} \mathrm{~min}^{-1}$. In both cases, at the fine fuel moisture content $9 \%$ scenario, the FIRETEC simulations were within the $20 \%$ nominal error range of FBP predictions; while in the moisture content $14 \%$ scenario, expected FBP system rate of spread, ROS, was only $30-50 \%$ of the simulated values. Despite the nearly 3 -fold increase in fuel loading relative to the FBP black spruce fuel type, simulated forward spread rates were similar to the FBP system values based observed prescribed burns in very similar fuel complexes, such as Hvenegaard et al. [13]. Unlike the Rothermel [30] and allied systems used in the US, fuel load in the Canadian FBP has no direct impact on rate of spread, and merely increases fire intensity via Byram's equation [31].

Previous studies, such as Hoffman et al. [32], have similarly pointed to the decreased skill of fire physics models in predicting the rate of spread at higher fuel moisture and lower wind speed conditions. However, in the context of suppression and community protection, such low intensity fires are easily discovered and suppressed at initial attack. Other advantages of fuel treatments, such as increased sightlines and hose laying rates, as well as improved aerial water drop effectiveness and ease 
of movement, are likely to outweigh any small alterations in fire growth in high fuel moisture and low wind speed conditions.

Other important considerations, such as the impact of fuel treatment on air tanker drop patterns of water or retardant, are not explicitly modelled here, nor are factors such as fire crew line construction rate [33], crew mobility on foot, or sprinkler effectiveness distances [34]. Though the movement of water through a forest canopy, be it from a helicopter bucket, air tanker, or sprinkler, is largely a physics problem, current fire fluid dynamics models are not able to simulate the process. Alongside factors such as fuel treatment cost and community acceptance, it is the net result of considerations surrounding fire behavior, suppression impacts, economics, and social acceptance that determines the ability to place fuel treatments on the landscape.

Despite attempts to capture as many of the key physical processes known to impact fire as possible, the formulation of this version of the FIRETEC model and resolution used in this study does have limitations. The largest single known limitation in this study is the inability of FIRETEC to resolve moisture content differences between surface fuels and the small amount of canopy fuels below $1.5 \mathrm{~m}$ above the forest floor. All fuels (surface fuels and canopy) are combined together and moisture contents averaged, so the impact of fine fuel moisture content on fire behavior is muted compared to experimental burning studies and the Canadian Forest Fire Behavior Prediction System overall. In open mulch patches, the fine fuel moisture content effect is more pronounced and in line with expectations from the FBP. Recent work has been done to improve FIRETEC's ability to resolve multiple co-existing fuels, retaining explicit representation of variations in moisture and surface area per unit volume within computational cells, and these new capabilities will be utilized for future work.

\section{Conclusions}

Results from this modelling exercise, combined with empirical observations, provide consistent evidence that strip mulching in boreal spruce stands will not limit crown fire or ember generation. Irregular pattern mulching with larger gaps shows promise in this modelling study, as a more desirable approach that reduces both spread rate as well as firebrand generation. The results support an effort to conduct test burns to evaluate an irregular mulch pattern treatment.

Supplementary Materials: The following are available online at http://www.mdpi.com/2571-6255/3/2/18/s1, Document S1: Detailed fuel model descriptions, Table S1: Summary outputs of the fuel structure, Table S2: Domain-averaged fire behavior outputs from the FIRETEC model.

Author Contributions: Conceptualization, G.M., D.K.T., K.A., B.S., R.L. and D.S.; methodology, G.M., D.K.T., K.A., B.S., R.L. and D.S.; software, G.M.; formal analysis, G.M.; writing—original draft preparation, D.K.T. and G.M.; writing-review and editing, all; visualization, G.M. and D.K.T.; project administration, all.; funding acquisition, K.A and D.K.T. All authors have read and agreed to the published version of the manuscript.

Funding: This research was funded by the Province of Alberta's Wildfire Management Science and Technology Program.

Conflicts of Interest: The funders had no role in the design of the study; in the analyses, or interpretation of data; in the writing of the manuscript, or in the decision to publish the results. Dave Schroder was a project team member, as designated by the funder, and provided input on study design and fuels modelling, but was not responsible for analysis or results.

\section{References}

1. Cohen, J.E.; Deeming, J.D. The National Fire-Danger Rating System: Basic Equations; General Technical Report PSW-82; Pacific Southwest Forest and Range Experiment Station: Berkeley, CA, USA, 1985.

2. Stocks, B.J.; Lynham, T.J.; Lawson, B.D.; Alexander, M.E.; Van Wagner, C.E.; McAlpine, R.S.; Dubé, D.E. Canadian Forest Fire Danger Rating System: An Overview. For. Chron. 1989, 65, 258-265. [CrossRef]

3. Coen, J.L. Modeling Wildland Fires: A Description of the Coupled Atmosphere-Wildland Fire Environment Model (CAWFE); Tech. Note NCAR/TN-500+ STR; National Center for Atmospheric Research, NCAR Library: Boulder, CO, USA, 2013. 
4. Morvan, D. Physical Phenomena and Length Scales Governing the Behaviour of Wildfires: A Case for Physical Modelling. Fire Technol. 2010, 47, 437-460. [CrossRef]

5. Linn, R.; Reisner, J.; Colman, J.J.; Winterkamp, J. Studying wildfire behavior using FIRETEC. Int. J. Wildland Fire 2002, 11, 233-246. [CrossRef]

6. Linn, R.; Anderson, K.; Winterkamp, J.; Brooks, A.; Wotton, M.; Dupuy, J.-L.; Pimont, F.; Edminster, C. Incorporating field wind data into FIRETEC simulations of the International Crown Fire Modeling Experiment (ICFME): Preliminary lessons learned. Can. J. For. Res. 2012, 42, 879-898. [CrossRef]

7. Hoffman, C.; Linn, R.; Parsons, R.; Sieg, C.; Winterkamp, J. Modeling spatial and temporal dynamics of wind flow and potential fire behavior following a mountain pine beetle outbreak in a lodgepole pine forest. Agric. For. Meteorol. 2015, 204, 79-93. [CrossRef]

8. Beaudoin, A.; Bernier, P.Y.; Villemaire, P.; Guindon, L.; Guo, X.J. Tracking forest attributes across Canada between 2001 and 2011 using a k nearest neighbors mapping approach applied to MODIS imagery. Can. J. For. Res. 2018, 48, 85-93. [CrossRef]

9. Forestry Canada Fire Danger Group. Development and Structure of the Canadian Forest Fire Behavior Prediction System; Information Report ST-X-3; Forestry Canada, Science and Sustainable Development Directorate: Ottawa, ON, Canada, 1992; ISBN 0662198123.

10. Alonzo, M.; Morton, D.C.; Cook, B.D.; Andersen, H.-E.; Babcock, C.; Pattison, R. Patterns of canopy and surface layer consumption in a boreal forest fire from repeat airborne lidar. Environ. Res. Lett. 2017, 12, 065004. [CrossRef]

11. Rogers, B.M.; Soja, A.J.; Goulden, M.; Randerson, J.T. Influence of tree species on continental differences in boreal fires and climate feedbacks. Nat. Geosci. 2015, 8, 228-234. [CrossRef]

12. Flat Top Complex Wildfire Review Committee. Flat Top Complex: Final Report from the Flat Top Complex Wildfire Review Committee; Agriculture and Forestry: Edmonton, AB, Canada, 2012; ISBN 9781460102701.

13. Hvenegaard, S.; Schroeder, D.; Thompson, D. Fire Behaviour in Black Spruce Forest Fuels Following Mulch Fuel Treatments: A Case Study at Red Earth Creek Alberta; Technical Report no. 42; FP Innovations Wildfire Operations Research Group: Hinton, AB, Canada, 2016.

14. Butler, B.W.; Ottmar, R.; Rupp, T.; Jandt, R.; Miller, E.; Howard, K.; Schmoll, R.; Theisen, S.; Vihnanek, R.; Jimenez, D. Quantifying the effect of fuel reduction treatments on fire behavior in boreal forests. Can. J. For. Res. 2013, 43, 97-102. [CrossRef]

15. Rupp, T.S.; Ottmar, R.; Butler, B. Quantifying the Effects of Fuels Reduction Treatments on Fire Behavior and Post-Fire Vegetation Dynamics; Final Report Project 06-2-1-39; Joint Fire Science Program: Fairbanks, AK, USA, 2011.

16. Little, J.; Jandt, R.; Drury, S.; Molina, A.; Lane, B. Evaluating the Effectiveness of Fuel Treatments in Alaska; Final Report Project 14-5-01-27; Joint Fire Science Program: Fairbanks, AK, USA, 2019.

17. Harris, C.; Fremon, L.; Price, O.; Boehr, W. 14LA-Lagoon Fire May 21, 2014 Case Study: How Fuel Treatment Areas Affect Wildland Urban Interface Fires; Information Report; Saskatchewan Ministry of Environment, Wildfire Management Branch: Prince Albert, SK, Canada, 2014.

18. Alexander, M.E.; Stefner, C.N.; Mason, J.A.; Stocks, B.J.; Hartley, G.R.; Maffey, M.E.; Wotton, B.M.; Taylor, S.W.; Lavoie, N.; Dalrymple, G.N. Characterizing the Jack Pine-Black Spruce Fuel Complex of the International Crown Fire Modelling Experiment (ICFME); Canadian Forest Service, Northern Forestry Centre: Edmonton, AB, Canada, 2004.

19. Cruz, M.G.; Alexander, M.E.; Sullivan, A.L. Mantras of wildland fire behaviour modelling: Facts or fallacies? Int. J. Wildland Fire 2017, 26, 973. [CrossRef]

20. Van Wagner, C.E. Development and Structure of the Canadian Forest Fire Weather Index System; Forestry Technical Report 35; Canadian Forest Service, Petawawa Forest Experiment Station: Ottawa, ON, Canada, 1987.

21. Chrosciewicz, Z. Foliar moisture content variations in four coniferous tree species of central Alberta. Can. J. For. Res. 1986, 16, 157-162. [CrossRef]

22. Thompson, D.K.; Schiks, T.; Wotton, B. Fuel size impacts on carbon residuals and combustion dynamics in masticated woody debris. For. Ecol. Manag. 2016, 369, 59-65. [CrossRef]

23. Kettridge, N.; Thompson, D.K.; Bombonato, L.; Turetsky, M.R.; Benscoter, B.; Waddington, J.M. The ecohydrology of forested peatlands: Simulating the effects of tree shading on moss evaporation and species composition. J. Geophys. Res. Biogeosciences 2013, 118, 422-435. [CrossRef] 
24. Koo, E.; Linn, R.R.; Pagni, P.J.; Edminster, C.B. Modelling firebrand transport in wildfires using HIGRAD/FIRETEC. Int. J. Wildland Fire 2012, 21, 396-417. [CrossRef]

25. Cruz, M.G.; E Alexander, M.; Wakimoto, R.H. Development and testing of models for predicting crown fire rate of spread in conifer forest stands. Can. J. For. Res. 2005, 35, 1626-1639. [CrossRef]

26. Burke, C.S. Investigating the Relationship between Horizontal Forest Structure and Fire Behavior Using a Physics-Based Fire Model. Master's Thesis, Colorado State University, Fort Collins, CO, USA, 2017.

27. Parsons, R.A.; Pimont, F.; Wells, L.; Cohn, G.; Jolly, W.M.; De Coligny, F.; Rigolot, E.; Dupuy, J.-L.; Mell, W.; Linn, R.R. Modeling thinning effects on fire behavior with STANDFIRE. Ann. For. Sci. 2018, 75, 7. [CrossRef]

28. Ziegler, J.P.; Hoffman, C.; Battaglia, M.; Mell, W. Spatially explicit measurements of forest structure and fire behavior following restoration treatments in dry forests. For. Ecol. Manag. 2017, 386, 1-12. [CrossRef]

29. Van Der Kamp, D.; Moore, R.; McKendry, I. A model for simulating the moisture content of standardized fuel sticks of various sizes. Agric. For. Meteorol. 2017, 236, 123-134. [CrossRef]

30. Rothermel, R.C. A Mathematical Model for Predicting Fire Spread in Wildland Fuels; US Department of Agriculture, Intermountain Forest and Range Experiment Station: Ogden, UT, USA, 1972.

31. Byram, G.M. Combustion of forest fuels. In Forest Fire: Control and Use; Davis, K.P., Ed.; McGraw-Hill: New York, NY, USA, 1959; pp. 61-89.

32. Hoffman, C.M.; Canfield, J.; Linn, R.R.; Mell, W.; Sieg, C.H.; Pimont, F.; Ziegler, J. Evaluating Crown Fire Rate of Spread Predictions from Physics-Based Models. Fire Technol. 2015, 52, 221-237. [CrossRef]

33. Hirsch, K.; Martell, D. A Review of Initial Attack Fire Crew Productivity and Effectiveness. Int. J. Wildland Fire 1996, 6, 199-215. [CrossRef]

34. Barnes, D.E. Fuel Moisture Changes from Sprinkler-Watering Treatments in Interior Alaska Boreal Forests. Master's Thesis, University of Alberta, Edmonton, AB, Canada, 2017.

(C) 2020 by the authors. Licensee MDPI, Basel, Switzerland. This article is an open access article distributed under the terms and conditions of the Creative Commons Attribution (CC BY) license (http://creativecommons.org/licenses/by/4.0/). 